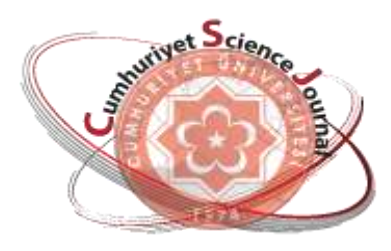

e-ISSN: 2587-246X

ISSN: $2587-2680$

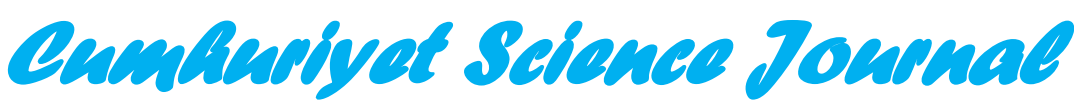

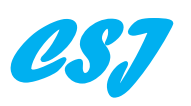

Cumhuriyet Sci. J., Vol.39-1(2018) 192-195

\title{
Lattice Energies for Groups 1 and 2 Halides from Absolute Hardness
}

\author{
Robson Fernandes de FARIAS ${ }^{1}$, Savaş KAYA ${ }^{2 *}$ \\ ${ }^{1}$ Universidade Federal do Rio Grande do Norte, Cx. Postal 1664, 59078-970, Natal/RN, BRASIL \\ ${ }^{2}$ Department of Chemistry, Faculty of Science, Cumhuriyet University, 58140, Sivas, TURKEY \\ Received: 22.10.2017; Accepted: 09.03.2018 \\ http://dx.doi.org/10.17776/csj.345660
}

\begin{abstract}
In this work, we presented new empirical equations to calculate the lattice energy values of groups 1 and 2 halides based on absolute hardness values of cations and anions forming the ionic compound.

For group 1 halides: $U_{P O T}=\left(-0.494 r^{+}+122.392\right)\left(\eta^{+}+\eta^{-}\right)-109.514 \eta^{+}+1191.694$

and for group 2 halides: $U_{P O T}=\left(-0.781 r^{+2}+251.255\right)\left(\eta^{+2}+\eta^{-}\right)-222.245 \eta^{+2}+2427.356$

In the given equations, $\mathrm{r}^{+}$and $\mathrm{r}^{+2}=$ cation radius $(\mathrm{pm}) ; \eta^{+}$and $\eta^{+2}=$ cation absolute hardness $(\mathrm{eV})$ and $\eta^{-}=$anion absolute hardness $(\mathrm{eV})$. Here, it should be noted that calculated lattice energy values for mentioned ionic compounds are in good agreement with the reference values obtained from the literature.
\end{abstract}

Keywords: Lattice energy, Absolute hardness, Empirical equation, Halides

\section{Kimyasal Sertlikten Grup 1 ve 2 Halojenürlerin Örgü Enerjileri}

Özet: Bu çalışmada grup 1 ve 2 halojenürlerin örgü enerjilerini hesaplamak için iyonik bileşiği oluşturan katyon ve anyonların mutlak sertlik değerlerine dayalı yeni denklemler türetilmiştir.

Grup 1 halojenürler için: $U_{P O T}=\left(-0.494 r^{+}+122.392\right)\left(\eta^{+}+\eta^{-}\right)-109.514 \eta^{+}+1191.694$

Grup 2 halojenürler için: $U_{P O T}=\left(-0.781 r^{+2}+251.255\right)\left(\eta^{+2}+\eta^{-}\right)-222.245 \eta^{+2}+2427.356$

Verilen denklemlerde, $\mathrm{r}^{+}$ve $\mathrm{r}^{+2}=$ katyon yarıçapı $(\mathrm{pm}) ; \eta^{+}$ve $\eta^{+2}=$ katyon mutlak sertliği $(\mathrm{eV})$. $\eta^{-}=$anyon mutlak sertliği (eV). Belirtilmelidir ki, çalışmada dikkate alınan iyonik bileşikler için elde edilen denklemler aracılığıyla hesaplanan örgü enerjisi değerleri, literatürden elde edilen referans değerler ile uyum içerisindedir.

Anahtar Kelimeler: Örgü enerjisi, mutlak sertlik, yeni denklemler, halojenürler

\section{INTRODUCTION}

It is known that lattice energy (U) is the energy required to decompose the solid into its constituent independent gaseous ions and this energy is a measure of the stability of inorganic ionic solids. Lattice energy is a prominent parameter in chemistry, since it could be related with a series of properties of a given compound, such as solubility, melting point, etc. Recently, R.F de Farias used the lattice energies to provide the thermochemical explanation for the stability of unusual compounds such as $\mathrm{NaCl}_{3}$ and $\mathrm{NaCl}_{7}$ [1]. 
In the current literature, there are many empirical equations proposed to calculate the lattice energies of inorganic ionic solids. GlasserJenkins [2] and Kaya [3] equations are some of well-known lattice energy equations and they provide very compatible results with experimental data reported. Glasser-Jenkins and Kaya lattice energy equations are given below, respectively.

$$
\begin{aligned}
& U / k J m o l^{-1}=2 I\left[\frac{\alpha}{V_{m}^{1 / 3}}+\beta\right] \\
& U / k J m o l^{-1}=2 I\left[a \frac{\eta_{M}}{V_{m}^{1 / 3}}+b\right]
\end{aligned}
$$

In these equations, $U, V_{m}$ and $\eta_{M}$ represent the lattice energy, molar volume and molecular hardness, respectively. $a, b, \alpha$ and $\beta$ parameters appearing in the mentioned equations are constants that take different numerical values for for various stoichiometries. $I$ is the ionic strength of the lattice which is simply calculated in terms of the number and type of ions with charge $z_{i}$ entering the unit formula, namely, $I=1 / 2 \sum n_{i} z_{i}^{2}$.
Most recently, Farias [4] developed an empirical equation to calculate the lattice energies of metal monohalides from average orbital electronegativities. The aim of the present work is to derive new and useful formulas to calculate the lattice energies of groups 1 and 2 halides based on absolute hardness [5] values of cations and anions in the solids.

\section{METHODOLOGY}

In the Conceptual Density Functional Theory, absolute hardness $(\eta)$ is calculated with the help of ground state ionization energy (I) and ground state electron affinity values (A) [6] of chemical species as $\eta=(I-A) / 2$. Using ionization energy and electron affinity values reported in the literature, absolute hardness values for $\mathrm{Li}^{+}$ (35.12), $\mathrm{Na}^{+}(21.08), \mathrm{K}^{+}(13.64), \mathrm{Rb}^{+}(11.56)$ and $\mathrm{Cs}^{+}$(9.61); $\mathrm{F}^{-}$(7.01), $\mathrm{Cl}^{-}$(4.70), $\mathrm{Br}^{-}$(4.24) and $\mathrm{I}^{-}$ (3.70) were calculated. Using such values, as well as reference values [2,7] for the lattice energies for the respective halides, an empirical equation was derived:

$$
U_{P O T}=\left(-0.494 r^{+}+122.392\right)\left(\eta^{+}+\eta^{-}\right)-109.514 \eta^{+}+1191.694
$$

where $\mathrm{r}^{+}=$cation radius $(\mathrm{pm}) ; \eta^{+}=$cation absolute hardness $(\mathrm{eV})$ and $\eta^{-}=$anion absolute hardness (eV). For each group of halides, a specific empirical equation with very high accuracy can be derived. For $\mathrm{Li}^{+}$halides, for instance, $U_{\text {POT }}=89.232\left(\eta^{+}+\eta^{-}\right)-2726.668(r=0.999)$ However, despite some lack of accuracy, the main interest here is to obtain general equations, such as Eq. (1).

For group 2 cations, the absolute hardness values
(eV) were calculated as $\mathrm{Be}^{2+}$ (67.84), $\mathrm{Mg}^{2+}$ (32.56), $\mathrm{Ca}^{2+}$ (19.52), $\mathrm{Sr}^{2+}$ (15.93) and $\mathrm{Ba}^{2+}$ (13.66). For each group of halides, very accurate equations can be obtained. For $\mathrm{Mg}^{2+}$ halides, for example,

9) $U_{\text {POT }}=191.777\left(\eta^{+}+\eta^{-}\right)-4609.108(r=0.999)$.

However, as stated previously, the main purpose here is to obtain general equations. So, for the group 2 halides, the following equation was derived:

$$
U_{P O T}=\left(-0.781 r^{+2}+251.255\right)\left(\eta^{+2}+\eta^{-}\right)-222.245 \eta^{+2}+2427.356
$$

where $\mathrm{r}^{+2}=$ cation radius $(\mathrm{pm}) ; \eta^{+2}=$ cation absolute hardness $(\mathrm{eV})$ and $\eta^{-}=$anion absolute hardness $(\mathrm{eV})$. To prove the validity of Eq.3 and
Eq.4, we compared our results with reference values. For all cations, the employed ionic radius (pm) was for coordination number 6 , as follows 
[8,9]: $\mathrm{Li}^{+}$(76), $\mathrm{Na}^{+}(102), \mathrm{K}^{+}(138), \mathrm{Rb}^{+}(152), \mathrm{Cs}^{+}$ (167), $\mathrm{Be}^{2+}(45), \mathrm{Mg}^{2+}$ (72), $\mathrm{Ca}^{2+}(100), \mathrm{Sr}^{2+}$ (118) and $\mathrm{Ba}^{2+}(135)$.

\section{RESULTS and DISCUSSION}

Chemical hardness is defined as resistance towards electron cloud polarization or deformation of chemical species. Hard and Soft Acid-Base Principle and Maximum Hardness Principle are the electronic structure principles based on chemical hardness concept. The obtained results are summarized in Tables 1 and 2. The derived equation shows that, given a certain cation, the lattice energy is dependent only on the anion absolute hardness. Furthermore, differing from Kapustinskii [10] equation, Eq. (3) and (4) do not require the anion radius. Furthermore, differing from Kaya equation [3] there is not a molar volume $\left(\mathrm{V}_{\mathrm{m}}\right)$ term. Hence, no information about the lattice parameters of the considered halide is necessary.

As can be verified, Eq. (3) and (4) works very well, specially Eq.(4). In Figure 1, graphical comparison with reference values of the results obtained using Eq. 4 is given. For group 2 halides. For the shown curve, $r=0.995$.

The great advantage of the proposed equations is their simplicity: only cation radius and ionization energies (to calculate the absolute hardness for cations and anions) are required, and such data are easily available for almost all elements of the periodic table. Hence, Eq. (3) and (4) are easily employable.

In conjunction with Kapustinskii equation, Equation (3) was successfully employed to calculated the first and second ionization energies for the super heavy element 119 [11], attesting their reliability and usefulness.
Table 1. Lattice energy values for Li to Cs halides (using Eq. 3).

\begin{tabular}{lccc}
\hline & $\mathrm{U}_{\text {POT }}\left(\mathrm{kJmol}^{-1}\right)$ Ref. & $\mathrm{U}_{\text {РОт }}\left(\mathrm{kJmol}^{-1}\right)$ Eq. 3 & $\Delta \%$ \\
\hline $\mathbf{L i F}$ & 1030 & 920 & -10.7 \\
\hline $\mathbf{L i C l}$ & 834 & 724 & -13.2 \\
\hline $\mathbf{L i B r}$ & 788 & 685 & -13.1 \\
\hline $\mathbf{L i I}$ & 730 & 639 & -12.5 \\
\hline $\mathbf{N a F}$ & 910 & 906 & 0.4 \\
\hline $\mathbf{N a C l}$ & 769 & 739 & -3.9 \\
\hline $\mathbf{N a B r}$ & 732 & 706 & -3.6 \\
\hline $\mathbf{N a I}$ & 682 & 667 & -2.2 \\
\hline $\mathbf{K F}$ & 808 & 818 & +1.2 \\
\hline $\mathbf{K C l}$ & 701 & 692 & -1.3 \\
\hline $\mathbf{K B r}$ & 671 & 667 & -0.6 \\
\hline $\mathbf{K I}$ & 632 & 638 & +0.9 \\
\hline $\mathbf{R b F}$ & 774 & 804 & +3.9 \\
\hline $\mathbf{R b C l}$ & 680 & 695 & +2.2 \\
\hline $\mathbf{R b B r}$ & 632 & 673 & +6.5 \\
\hline $\mathbf{R b I}$ & 617 & 648 & +5.0 \\
\hline $\mathbf{C s F}$ & 759 & 802 & +5.7 \\
\hline $\mathbf{C s C l}$ & 670 & 710 & +6.0 \\
\hline $\mathbf{C s B r}$ & 647 & 692 & +7.0 \\
\hline $\mathbf{C s I}$ & 613 & 670 & +9.3 \\
\hline
\end{tabular}

Table 2. Lattice energy values for Be to Ba halides (using Eq. 4).

\begin{tabular}{|c|c|c|c|}
\hline & $\mathrm{UPOT}\left(\mathrm{kJmol}^{-1}\right)$ Ref. & $\mathrm{UPOT}_{\text {РО }}\left(\mathrm{kJmol}^{-1}\right)$ Eq. 4 & $\Delta \%$ \\
\hline $\mathrm{BeF}_{2}$ & 3526 & 3526 & 0.0 \\
\hline $\mathbf{B e C l}_{2}$ & 3033 & 3027 & -0.2 \\
\hline $\mathrm{BeBr}_{2}$ & 2914 & 2927 & +0.4 \\
\hline $\mathrm{BeI}_{2}$ & 2813 & 2811 & -0.1 \\
\hline $\mathrm{MgF}_{2}$ & 2978 & 2908 & -2.4 \\
\hline $\mathrm{MgCl}_{2}$ & 2540 & 2458 & -3.2 \\
\hline $\mathrm{MgBr}_{2}$ & 2451 & 2368 & -3.4 \\
\hline $\mathbf{M g I}_{2}$ & 2340 & 2263 & -3.3 \\
\hline $\mathrm{CaF}_{2}$ & 2651 & 2683 & +1.2 \\
\hline $\mathrm{CaCl}_{2}$ & 2271 & 2283 & -0.5 \\
\hline $\mathrm{CaBr}_{2}$ & 2134 & 2203 & +3.2 \\
\hline $\mathrm{CaI}_{2}$ & 2087 & 2110 & +1.1 \\
\hline $\mathrm{SrF}_{2}$ & 2513 & 2537 & +1.0 \\
\hline $\mathrm{SrCl}_{2}$ & 2170 & 2169 & 0.0 \\
\hline SrBr2 & 2040 & 2096 & +2.7 \\
\hline $\mathrm{SrI}_{2}$ & 1976 & 2010 & +1.7 \\
\hline $\mathrm{BaF}_{2}$ & 2373 & 2406 & +1.4 \\
\hline $\mathrm{BaCl}_{2}$ & 2069 & 2069 & 0.0 \\
\hline $\mathrm{BaBr}_{2}$ & 1995 & 2002 & +0.4 \\
\hline $\mathrm{BaI}_{2}$ & 1890 & 1923 & +1.7 \\
\hline
\end{tabular}




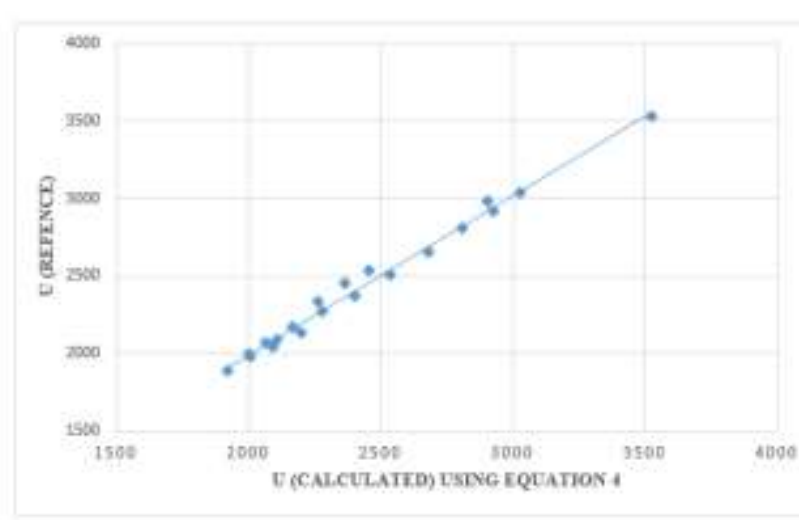

Figure 1. Comparison with reference values of the results obtained using Eq.4.

\section{REFERENCES}

[1]. Fernandes De Farias R., Computational GasPhase Formation Enthalpy and Electron Affinity for Platinum Hexafluoride: Is Gaseous PtF6 Diamagnetic because of a Relativistic Effect?, Inorg. Chem., 55-23 (2016) 12126-12127.

[2]. Glasser L. and Jenkins H. D. B., Lattice energies and unit cell volumes of complex ionic solids., J. Am. Chem. Soc., 122-4 (2000) 632-638.

[3]. Kaya S. and Kaya C., A simple method for the calculation of lattice energies of inorganic ionic crystals based on the chemical hardness, Inorg. Chem., 54-17 (2015) 8207-8213.
[4]. Fernandes De Farias R., Estimation of some physical properties for tennessine and tennessine hydride (TsH), Chem. Phys. Lett., 667 (2017) 1-3.

[5]. Putz M.V., Absolute and chemical electronegativity and hardness, Nova Science Publishers, New York, 2009.

[6]. Brus L. E. A simple model for the ionization potential, electron affinity, and aqueous redox potentials of small semiconductor crystallites, J. Chem. Phys. 79 (1983) 55665571.

[7]. Mu L., Feng, C. and He, H., Topological research on lattice energies for inorganic compounds. MATCH Commun. Math. Comput. Chem., 56 (2006) 97-111.

[8]. CRC Handbook of Chemistry and Physics, 96th ed., Taylor and Francis, Boca Raton, 2016.

[9]. Kaya S., Fernandes De Farias R., Absolute ion hydration enthalpies from absolute hardness and some VBT relationships, Chem. Phys. Lett., 691 (2008) 169-171.

[10]. Kapustinskii A. F., Lattice energy of ionic crystals. Quart. Rev. Chem. Soc., 10 (1956) 283-294.

[11]. De Farias R. F., Hybrid orbitals notation: Some misconceptions in an undergraduate basic chemistry course. African Journal of Chemical Education, 7 (2017) 2-8. 